As-Syifaa Jurnal Farmasi Desember 2019; 11 (02):147-153.

ISSN : 2085-4714

\title{
ISOLASI FUNGI ENDOFIT KULIT BUAH MERAH (Pandanus conoideus Lam.) YANG BERPOTENSI SEBAGAI ANTIBAKTERI SECARA METODE KLT - BIOAUTOGRAFI
}

\author{
Reza Ariyadi Deponda, Fitriana, Siska Nuryanti, Herwin
}

Fakultas Farmasi, Universitas Muslim Indonesia, Makassar

Email : fitriana.fitriana@umi.ac.id

\begin{abstract}
Red fruit (Pandanus conoideus Lam.) belongs to genus Pandanus. Red fruit oil has the activity as an antibacterial. The research aimed to obtain endophytic fungi isolates on the red fruit peel and assay the antibacterial activity by TLC-Bioautography. The research was experimentally conducted including the process of isolation of endophytic fungi, purification, macroscopic examination, screening for antibacterial activity against Staphylococcus aureus and Salmonella typhi, fermentation for 7, 14 and 21 days, separation and antibacterial assay by TLC-Bioautography against Staphylococcus aureus and Salmonella typhi, the isolate fermentate of endophytic fungi for 7 days showed an Rf value of 0.49 against Staphylococcus aureus and an 0.47 against Salmonella typhi. The isolate fermentate of endophytic fungi for 14 days showed an $R f$ value of 0.58 against Staphylococcus aureus and an 0.69 against Salmonella typhi. The isolate fermentate of endophytic fungi for 21 days showed an Rf value of 0.69 against Staphylococcus aureus and an 0.67 against Salmonella typhi. In conclusion, red fruit peel had endophytic fungi isolate with the potency as an antibacterial.
\end{abstract}

Key words: Endophytic fungi, red fruit, antibacterial.

\section{PENDAHULUAN}

Tumbuhan obat merupakan sebagai salah satu sumber bahan baku obat yang dapat digunakan. Sebagian besar komponen kimia berasal dari tumbuhan yang dapat digunakan sebagai obat ataupun bahan obat adalah metobolit sekunder. ${ }^{1}$

Mlkroorganisme yang melekat pada bagian-bagian tumbuhan biasa disebut sebagai mikroba endofit. Mikroorgansime ini meliputi bakteri dan jamur serta hidup pada bagian akar, batang, daun maupun buah yang berasal dari suatu tumbuhan. ${ }^{2}$

Fungi endofit adalah fungi yang hidupnya di dalam jaringan tanaman dan mampu hidup dengan membentuk koloni dalam jaringan tanaman tanpa membahayakan inangnya. Fungi endofit yang dihasilkan dapat memproduksi senyawasenyawa metabolit sekunder yang hampir sama atau sesuai dengan tanaman inangnya. Fungi endofit yang telah dilakukan iisolasi dari suatu tanaman obat dapat menghasilkan senyawa-senyawa metabolit sekunder yang sama dengan tanaman aslinya, bahkan dalam jumlah yang lebih tinggi, sehingga tidak diperlukan memanen tanaman aslinya untuk mengambil sebagai simplisia yang kemungkinan besar memilki waktu puluhan tahun untuk menanamnya. ${ }^{1}$

Fungi endofit dapat diisolasi dari beberapa bagian tanaman, salah satunya yaitu pada kulit buah, seperti yang dilakukan oleh Roza (2013), dimana telah dilakukan karakterisasi fungi endofit dari kulit buah manggis (Garcinia mangostana L.) sebagai 
Isolasi fungi endofit kulit buah merah (Pandanus conoideus Lam.) yang berpotensi sebagai antibakteri secara metode KLT-Bioautografi

antimikroba, yang menunjukkan bahwa 11 dari 20 isolat fungi endofit berhasil diisolasi dari kulit buah manggis memiliki potensi aktivitas sebagai antimikroba. ${ }^{3}$

Buah Merah (Pandanus conoideus Lam.) adalah tanaman asli dari Papua yang termasuk genus Pandanus. Tumbuhan ini menyebar di Papua, Papua Nugini, dan mulai ditanam di beberapa daerah di Indonesia. ${ }^{4}$

Minyak buah merah memiliki kandungan asam oleat, $\beta$-karoten, $\beta$ cryptoxanthin, $\alpha$-tokoferol, senyawa fenolik dan flavonoid yang berpotensi sebagai obatobatan. Minyak buah merah minyak digunakan masyarakat setempat sebagai obat alami untuk banyak penyakit seperti kanker, rheumatoid arthritis, stroke dan HIV/AIDS. ${ }^{4}$

Menurut penelitian (Sundari, 2010) tentang Identifikasi Senyawa Dalam Ekstrak Etanol Biji Buah Merah (Pandanus Conoideus Lam.) hasil yang diperoleh menunjukkan bahwa ekstrak etanol biji buah merah memiliki senyawa yang berpotensi sebagai antibakteri. 5

Berdasarkan dari uraian tersebut, maka penelitian ini dilakukan untuk mengisolasi fungi endofit pada kulit buah merah (Pandanus conoideus Lam.) dan melakukan pengujian dengan menggunakan metode KLT Bioatografi terhadap bakteri patogen.

\section{METODE PENELITIAN}

\section{Alat dan bahan}

Adapun alat yang digunakan pada penelitian ini yaitu autoklaf (SMIC model YX280 B)cawan Petri (Normax), erlenmeyer (Iwaki Pyrex), gelas kimia 250 dan 500 ml (Iwaki Pyrex), inkubator (Memert), Lampu spiritus, Laminar Air Flow (LAF), lampu UV $254 \mathrm{~nm}$ dan $366 \mathrm{~nm}$, oven (Memert), pipa kapiler, shaker, timbangan analitik (Chyo). ${ }^{6}$ Adapun bahan yang digunakan pada penelitian ini yaitu aquadest steril, etil asetat, kloramfenikol, lempeng KLT, mikroba uji (Staphylococcus aureus dan Salmonella typhi), medium Maltosa Yeast Broth (MYB), medium Nutrient Agar (NA), medium Potato Dextrosa Agar (PDA), $\mathrm{NaCl}$ fisiologis $0,9 \%$, dan sampel kulit buah merah (Pandanus conoideus Lam.).

\section{Prosedur Penelitian}

\section{Pengambilan dan penyiapan sampel}

Sampel penelitian yang digunakan berupa kulit buah merah (Pandanus conoideus Lam.) yang dikumpulkan dibersihkan dan dicuci dengan air mengalir. Selanjutnya didesinfeksi permukaan kulit (pot) buah merah (Pandanus conoideus Lam.) menggunakan etanol $70 \%$ selama \pm 2 menit, kemudian dibilas dengan aquadest steril sebanyak 3 kali masing-masing selama 1 menit. $^{6}$

\section{Isolasi Fungi Endofit}

Sampel permukaan kulit buah merah (Pandanus conoideus Lam.) dipotong kecilkecil menjadi $\pm 1 \mathrm{~cm}$. Potongan kecil tersebut diletakkan diatas medium Potato Dekstrosa Agar Chlorampenicol (PDAC) didalam cawan petri steril yang kemudian diinkubasi pada suhu $25^{\circ} \mathrm{C}-30^{\circ} \mathrm{C}$ selama 3 hari. Kloramfenikol $0,2 \mathrm{~g} / \mathrm{mL}$ sebelumnya ditambahkan kedalam media agar untuk mencegah pertumbuhan bakteri lainnya (Bara et al. 2015). Setelah 3-5 hari fungi yang tumbuh, kemudian diisolasi dan dilakukan inokulasi pada medium Potato Dekstrosa Agar (PDA) yang baru. Selama proses pekerjaan dilakukan secara aseptis didalam Laminar Air Flow (LAF). ${ }^{6}$

\section{Pemurnian dan pemeriksaan makroskopik}

Permurnian dilakukan dengan cara memindahkan masing-masing isolat fungi 
Isolasi fungi endofit kulit buah merah (Pandanus conoideus Lam.) yang berpotensi sebagai antibakteri secara metode KLT-Bioautografi

endofit ke media Potato Dekstrosa Agar (PDA)

yang baru, kemudian diinkubasi selama 3-5 hari pada suhu kamar. Pemurnian dilakukan sampai diperoleh isolat fungi endofit murni yang tunggal dan dilakukan analisis secara makroskopik dengan cara melihat langsung bentuk dan warna koloni. ${ }^{2}$

\section{Penyiapan bakteri uji}

\section{Peremajaan bakteri uji}

Bakteri uji yaitu Staphylococcus aureus dan Salmonella typhi masing-masing diambil satu ose lalu diinokulasikan dengan cara digoreskan pada medium Nutrient Agar miring lalu diinkubasi pada suhu $37^{\circ} \mathrm{C}$ selama $1 \times 24$ jam. Setelah itu dapat digunakan sebagai mikroba uji.

\section{Pembuatan suspensi bakteri uji}

Bakteri uji hasil peremajaan disuspensikan menggunakan larutan $\mathrm{NaCl}$ fisiologis $0,9 \%$, kemudian diukur kekeruhannya menggunakan spektrofotometer dengan kekeruhan 25\% Transisi. Pada panjang gelombang $580 \mathrm{~nm}$. Menggunakan bakteri uji Staphylococcus aureus dan Salmonella typhi. ${ }^{7}$

\section{Uji Skrining aktivitas antibakteri}

Isolat fungi endofit yang berukuran \pm $0,5 \mathrm{~cm}$ di inokulasikan kedalam medium NA yang telah berisi bakteri uji dimana isolat tersebut ditempelkan diatas permukaan media. Kemudian diinkubasi selama $1 \times 24$ jam pada suhu $37^{\circ} \mathrm{C}$ lalu diamati diamter zona hambat yang terbentuk. ${ }^{6}$

\section{Fermentasi isolat}

Fungi endofit yang memberikan aktivitas terbesar sebagai isolat terpilih selanjutnya ditumbuhkan pada medium Maltosa Yeast Broth (MYB), kemudian isolat fungi endofit yang tumbuh diambil dengan ose bulat lalu dimasukkan ke dalam erlenmeyer
$250 \mathrm{~mL}$ yang berisi $100 \mathrm{~mL}$ medium Maltosa Yeast Broth (MYB) untuk dilakukan fermentasi. Fermentasi secara dinamis menggunakan shaker dengan kecepatan 200 rpm selama 7, 14 dan 21 hari . ${ }^{8}$

\section{Ekstrak isolat}

Supernatan hasil fermentasi disaring untuk memisahkan supernatan dan miselia. Supernatan di ekstraksi dengan pelarut etil asetat $(1: 1 \mathrm{v} / \mathrm{v})$, kemudian pelarut diuapkan sampai diperoleh ekstrak kering.

\section{Identifikasi kromatografi lapis tipis (KLT)}

Lempeng KLT sebelum digunakan diaktifkan terlebih dahulu dengan pemanasan pada oven suhu $100^{\circ} \mathrm{C}$ selama 30 menit sebelum digunakan. Ekstrak fermentat dilarutkan dengan pelarut etil asetat kemudian ditotolkan pada lempeng KLT ukuran $7 \times 1 \mathrm{~cm}$ menggunakan pipa kapiler. Kemudian dielusi dengan menggunakan $\mathrm{n}$-heksan : etil asetat (4:1) dan lempeng di masukkan kedalam chamber. Lempeng kemudian dikeluarkan dari chamber dan diangin-anginkan sehingga cairan pengelusinya menguap. Kemudian kromatogram yang dihasilkan diamati nodanya dibawah sinar UV pada panjang gelombang $254 \mathrm{~nm}$ dan $366 \mathrm{~nm}^{9}$

\section{Pengujian secara KLT-Bioautografi}

Hasil identifikasi KLT menggunakan nheksan : etil asetat (4:1) dilanjutkan dengan uji KLT-Bioautografi dengan cara cawan petri dituang Nutrient Agar sebanyak $10 \mathrm{~mL}$ yang telah diinokulasikan dengan suspensi bakteri Staphylococcus aureus dan Salmonella typhi sebanyak 0,2 $\mathrm{mL}$ lalu dihomogenkan, lempeng KLT yang telah dielusi diletakkan diatas permukaan medium agar yang telah diinokulasikan dengan mikroba uji kemudian dibiarkan selama 60 menit. Setelah itu lempeng diangkat dan dikeluarkan, 
Isolasi fungi endofit kulit buah merah (Pandanus conoideus Lam.) yang berpotensi sebagai antibakteri secara metode KLT-Bioautografi

selanjutnya diinkubasi selama 1x24 jam pada

memberikan aktivitas penghambatan terhadap

suhu $37^{\circ} \mathrm{C}$ kemudian diamati bercak yang pertumbuhan bakteri uji. ${ }^{10}$

\section{HASIL PENELITIAN}

Tabel 1. Hasil pengujian KLT-Bioautografi dari kromatogram fermentat isolat fungi endofit kulit buah merah (Pandanus conoideus Lam.) dengan menggunakan eluen $n$-heksan : etil asetat (4: 1).

\begin{tabular}{ccccc}
\hline Kode Isolat & Fermentat & Rf & Diameter zona bening $(\mathbf{m m})$ & Bakteri \\
\hline & 7 hari & 0,49 & 17,12 & \\
& 14 hari & 0,58 & 12,66 & S.aureus \\
RB 04 & 21 hari & 0,69 & 14,06 & \\
& 7 hari & 0,47 & 15,42 & S. typhi \\
& 14 hari & 0,69 & 11,95 & \\
& 21 hari & 0,67 & 14,08 & \\
\hline
\end{tabular}

\section{PEMBAHASAN}

Buah merah (Pandanus conoideus Lam.) adalah tumbuhan yang berasal dari Papua dan banyak dipakai untuk pengobatan. Buah merah mengandung senyawa fenolik dan flavonoid yang berpotensi sebagai antibakteri. ${ }^{11}$

Penelitian ini dilakukan pengujian aktivitas antibakteri dari isolat fungi endofit kulit buah merah (Pandanus conoideus Lam.) menggunakan metode KLT-Bioautografi, dimana diketahui bahwa pengujian aktivitas antibakteri merupakan suatu metode yang digunakan untuk melihat potensi suatu senyawa yang dapat memberikan efek sebagai antibakteri bagi mikroorganisme. Sampel yang digunakan pada penelitian ini yaitu fungi endofit kulit buah merah (Pandanus conoideus Lam.).

Langkah pertama dalam penelitian ini yaitu isolasi, yang bertujuan untuk memperoleh kultur murni fungi endofit menggunakan medium Potato Dekstrosa Agar (PDA) yang telah ditambahkan dengan Kloramfenikol. Penambahan kloramfenikol bertujuan agar yang tumbuh adalah isolat fungi bukan bakteri. Kloramfenikol merupakan salah satu antibiotik berspektrum luas yang dapat menghambat atau membunuh pertumbuhan bakteri Gram positif dan Gram negatif. ${ }^{12}$

Isolat fungi endofit kulit buah merah (Pandanus conoideus Lam) yang diperoleh kemudian dilanjutkan ke uji pemurniaan yang bertujuan untuk memperoleh isolat fungi endofit murni yang tunggal. $^{13}$ Kemudian dilakukan pemeriksaan makroskopik untuk mengetahui bentuk morfologi isolat dengan melihat bentuk koloni, elevasi, tepi dan warna pada isolat murni yang terlah diperoleh dari hasil pemurnian.

Selanjutnya isolat yang diperoleh dilakukan pengujian skrining menggunakan 2 bakteri uji, yaitu Staphylococcus aureus dan Salmonella typhi, yang bertujuan untuk mengetahui aktivitas antibakteri terhadap bakteri yang diujikan. Hasil yang diperoleh menunjukkan bahwa isolat fungi endofit dengan kode RB03 dan RB04 memilik aktivitas sebagai antibakteri dilihat dari dimater zona hambatan yang terbentuk. Hal ini diperkuat oleh penelitian sebelumnya (Indrawati 2016) mengenai ekstrak buah merah (Pandanus conoideus Lam.), dimana pada penelitian tersebut diperoleh hasil ekstrak buah merah (Pandanus conoideus Lam.) memiliki aktivitas terhadap bakteri Staphylococcus aureus dan Salmonella 
Isolasi fungi endofit kulit buah merah (Pandanus conoideus Lam.) yang berpotensi sebagai antibakteri secara metode KLT-Bioautografi

typhi. ${ }^{14}$ Menurut Fitriana dan Eka 2017, klasifikasi respon hambat pertumbuhan bakteri jika diameter zona bening $>20 \mathrm{~mm}$ berarti kuat, $16-20 \mathrm{~mm}$ berarti sedang, 10-15 mm berarti lemah, dan $<10 \mathrm{~mm}=$ tidak ada. ${ }^{6}$

Hasil pengujian skrining menunjukan isolat fungi endofit kode RB04 menunjukan aktivitas antibakteri yang kuat dalam menghambat bakteri Staphylococcus aureus dan Salmonella typhi karena diameter zona hambatan yang terbentuk $>20 \mathrm{~mm}$. Sehingga inilah yang menjadi dasar pemilihan isolat fungi endofit dengan kode RB04 untuk dilanjutkan pada tahap proses fermentasi, yang bertujuan untuk meningkatkan produksi metabolit sekunder pada isolat. Proses fermentasi dilakukan selama 7, 14 dan 21 hari untuk memperoleh metabolt sekunder. ${ }^{15}$

Kemudian hasil dari fermentasi disaring untuk memisahkan supernatan dan miselia. Supernatan kemudian ditambahkan etil asetat sebagi pelarut kemudian diuapkan. Sehingga diperoleh ekstrak etil asetat dari supernatan. Pemilihan pelarut etil asetat adalah karena etil asetat bersifat semi polar yang dapat menarik senyawa polar dan non polar . ${ }^{16}$

Setelah diperoleh ektstrak etil asetat dari supernatan kemudian dilanjutkan pengujian KLT. Ekstrak etil astetat di totol pada lempeng KLT dan dielusi menggunakan eluen n-Heksan:etil asetat (1:4), kemudian kromatogram yang dihasilkan diamati di sinar UV pada panjang gelombang $254 \mathrm{~nm}$ dan 366 $\mathrm{nm}$.

Kemudian dilanjutkan dengan pengujian KLT-Bioautografi untuk mengamati aktivitas antibakteri terhadap bakteri uji. Proses pengujian dilakukan dengan menggunakan metode bioautografi kontak, dimana senyawa yang telah ditotolkan pada lempeng KLT yang dipindahkan ke medium agar yang telah diinokulasikan bakteri uji secara merata dan melakukan kontak langsung. ${ }^{17}$

Hasil yang diperoleh yaitu isolat fungi endofit kode RB04 memiliki nilai Rf 0,47 dan 0,69 yang memiiki aktivitas antibakteri terhadap bakteri uji Staphylococcus aureus dan Salmonella typhi. Aktivitas yang diberikan berupa zona bening, dimana zona bening atau zona hambat merupakan parameter adanya aktivitas antibakteri. Fermentat 7 hari memiliki diameter zona hambat yang paling besar terhadap bakteri uji Staphylococcus aureus dengan diameter sebesar 17,12 mm dan terhadap bakteri Salmonella typhi dengan diameter sebesar 15,42 mm.

$$
\text { Hasil pengujian KLT-Bioautografi }
$$

fermentat 7, 14 dan 21 hari bersifat menghambat pertumbuhan bakteri (bakteriostatik). Hal ini ditunjukkan dengan adanya perbedaan yang signifikan dari diameter zona hambat yang dihasilkan terhadap bakteri Staphylococcus aureus dan Salmonella typhi). ${ }^{18}$

Selain itu, juga didukung oleh pernyataan dari (Herlina et al. 2018) yang dikutip dari (Jawetz \& Adelberg, 2007) bahwa perbedaan kemampuan suatu ekstrak dalam menghambat atau menmbunuh pertumbuhan bakteri dapat dipengaruhi oleh sifat dari dinding sel bakteri karena bakteri Gram negatif dan Gram positif mempunyai dinding sel yang berbeda sensitivitasnya terhadap perlakuan fisik, enzim dan antibiotik. ${ }^{17}$

Stabilitas senyawa-senyawa aktif yang terkandung di dalam fermentat juga dapat mempengaruhi aktivitas antibakteri. Faktorfaktor yang mempengaruhi stabilitas senyawa 
Isolasi fungi endofit kulit buah merah (Pandanus conoideus Lam.) yang berpotensi sebagai antibakteri secara metode KLT-Bioautografi

aktif yaitu suhu, cahaya, udara (terutama oksigen, karbondioksida dan uap air) serta kelembaban. Faktor-faktor lain juga yang dapat mempengaruhi stabilitas senyawa aktif, yaitu sifat air dan kondisi biotik serta keberadaan bahan kimia lain yang merupakan kontaminan atau dari pencampuran produk yang berbeda secara aktif dapat mempengaruhi stabilitas senyawa aktif. ${ }^{18}$

Dari hasil penelitian yang diperoleh dapat disimpulkan bahwa isolat fungi endofit kulit buah merah (Pandanus conoideus Lam.) memiliki aktivitas sebagai antibakteri terhadap bakteri uji.

\section{KESIMPULAN}

Berdasarkan hasil penelitian yang dilakukan isolat fungi endofit kulit buah merah (Pandanus conoideus Lam.) memiliki aktivitas sebagai antibakteri terhadap bakteri Staphylococcus aureus dan Salmonella typhi. Adapun profil bioautogram dari ekstrak fermentat isolat fungi endofit kulit buah merah (Pandanus conoideus Lam.) pada fermentasi selama 7 hari menunjukkan nilai $\operatorname{Rf} 0,49$, fermentasi selama 14 hari menunjukkan nilai Rf 0,58 dan fermentasi selama 21 hari menunjukkan nilai $\operatorname{Rf}$ 0,69 terhadap bakteri Staphylococcus aureus. Fermentasi selama 7 hari diperoleh nilai Rf 0,47 , fermentasi selama 14 hari diperoleh nilai $\mathrm{Rf}$ 0,6 dan fermentasi selama 21 hari diperoleh nilai $\operatorname{Rf} \quad 0,67$ terhadap bakteri Salmonella typhi.

\section{DAFTAR PUSTAKA}

1. Radji M. Peranan Bioteknologi dan Mikroba Endofit dalam Pengembangan Obat Herbal. Majalah IImu Kefarmasian,2005;2(3):113-126.

2. Adriani. Aktivitas Antibakterial Fungi Endofit Caulerpa racemosa Terhadap Bakteri Escherichia coli dan Staphylococcus aureus. Makassar : UIN Alauddin, 2015.
3. Elfina D, Martina A, Roza RM. Isolasi Dan Karakterisasi Fungi Endofit Dari Kulit Buah Manggis (Garcinia mangostana L) Sebagai Antimikroba Terhadap Candida albicans, Staphylococcus aureus dan Escherichia coli. Jurnal Online Mahasiswa Fakultas Matematika dan IImu Pengetahuan Alam Universitas Riau 1.1 (2014).

4. Wismandanu O, Maulidya I, Indariani S, Batubara I. Acute Toxicity Of Red Fruits (Pandanus conoideus Lamk) Oil and The Hepatic Enzyme Level In Rat.The Journal of Phytopharmacology.2016;5(5):176-178.

5. Sundari I. Identifikasi Senyawa Dalam Ekstrak Etanol Biji Buah Merah (Pandanus conoideus Lam.) (Skripsi). Surakarta: Universitas Sebelas Maret, 2010.

6. Fitriana and Nursithya E. Aktivitas Antibakteri Ekstrak Isolat Fungi Endofit Dari Akar Mangrove (Rhizophora apiculata Blume) Secara KLT Bioautografi. AsSyifaa J Farm.2017;9(1):27-36.

7. Budiarti R, Husain DR, Hasyim Z and Abdullah A. Kemampuan Beberapa Isolat Bakteri Endosimbion Cacing Tanah Lumbricus rubellus Dalam Menghambat Pertumbuhan Bakteri Salmonella thypi dan Staphylococcus aureus (Skripsi). Makassar: Universitas Hasanuddin, 2016.

8. Kumala S. Mikroba Endofit Pemanfaatan Mikroba Endofit dalam Bidang Farmasi. Jakarta: ISFI, 2014.

9. Sastrohamijodjo H. Kromatografi. Yogyakarta: Liberti, 2002.

10. Mustary M, Djide MN, Mahmud I, Hasyim N. Uji Daya Hambat dan Analisis KLTBioautografi Perasan Buah Sawo Manila (Achras zapota Linn) Terhadap Bakteri Uji Salmonella thyposa. Jurnal MKMI.2011;7(1):25-27.

11. Andhika OA. Efek fitopreventif minyak buah merah (Pandanus conoideus Lam.) Terhadap Colitis-Associated Carcinogenesis. Journal of Medicine and Health.2015;1(2):126-142.

12. Kemenkes. Pedoman Umum Penggunaan Antibiotik. Jakarta: Kementrian Kesehatan RI, 2011. 
Isolasi fungi endofit kulit buah merah (Pandanus conoideus Lam.) yang berpotensi sebagai antibakteri secara metode KLT-Bioautografi

13. Franciska A, Darwis W. Pembuatan Isolat Jamur Obat Picnoporus sanguineus. Bengkulu: Universitas Bengkulu, 2013.

14. Indrawati I. Sensitivity of Pathogenic Bacteria to Buah Merah (Pandanus conoideus Lam.). Bandung: Universitas Padjadjaran, 2016.

15. Kursia S, Aksa R, Nolo MM. Potensi Antibakteri Isolat Jamur Endofit Dari Daun Kelor (Moringa oleifera Lam.). Pharmauho.2018;4(1):30-33.

16. Tensiska $M$ dan Yuidiastuti SON. Pengaruh Jenis Pelarut Terhadap aktivitas Antioksidan Ekstrak Kasar Isoflavon dari Ampas Tahu (Skripsi). Bali: Fakultas Matematika dan IImu Pengetahuan Alam, Universitas Udayana, 2007

17. Yudiastuti SON, Tensiska, Marsetio. Pengaruh jenis pelarut terhadap aktivitas antioksidan ekstrak kasar isoflavon dari ampas tahu.Teknotan.2007;1(3).
18. Herlina R, Yasir Y, Semsuli. Deteksi Antimikroba Secara KLT-Bioautografi Ekstrak Buah Belimbing Wuluh (Averrhoa blimbi Linn.). Makassar:Universitas Hasanuddin, 2018.

19. Rante H, Yasir Y, Semsuli SNAE. Detection of Antimicrobial Compounds by Bioautography from Star Fruit (Averrhoa bilimbi Linn). Journal of Pharmaceutical and Medicinal Sciences. 2018;3(1):1-5.

20. Marselia S, Wibowo MA, Arreneuz S. Aktivitas Antibakteri Ekstrak Daun Soma (Ploiarium alternifolium Melch) Terhadap Propionibacterium acnes. Jurnal Kimia Khatulistiwa.2014;4(4):72-82.

21. Dhuha S, Bodhi W, Kojong N. Aktivitas Antibakteri Ekstrak Etanol Daun Lamun (Syiringodium isoetifolium) Terhadap Bakteri Pseudomonas aeruginosa. Pharmacon Jur IIm Farm.2016;5(1):231237. 